\title{
JIURNAL of Nutritidon Callege
}

Volume 9, Nomor 2, Tahun 2020, Halaman 106-113

Online di : http://ejournal3.undip.ac.id/index.php/jnc/

Submitted : 29 Maret 2020

Accepted : 31 Mei 2020

\section{ASI EKSKLUSIF DAN ASUPAN ENERGI BERHUBUNGAN DENGAN KEJADIAN STUNTING} PADA USIA 6 - 24 BULAN DI JAWA TENGAH

\author{
Dini Nugraheni ${ }^{1}$, Nuryanto ${ }^{1,2^{*}}$, Hartanti Sandi Wijayanti ${ }^{1,2}$, Binar Panunggal ${ }^{1,2}$, Ahmad Syauqy ${ }^{1,2}$ \\ ${ }^{1}$ Departemen Ilmu Gizi, Fakultas Kedokteran, Universitas Diponegoro. Jln. Prof Soerdarto SH, Tembalang Semarang 50275, Indonesia. \\ ${ }^{2}$ Center of Nutrition Research (CENURE), Fakultas Kedokteran, Universitas Diponegoro. Jln. Prof Soerdarto SH, Tembalang Semarang 50275, \\ Indonesia. *Penulis Penanggungjawab : nyt_gizi@yahoo.com
}

\begin{abstract}
Background: Stunting is a picture of chronic nutritional deficiency. There were many factors associated with stunting. The objective of the study was to determine the relationship between a history of early breastfeeding initiation (IMD), a history of exclusive breastfeeding, a history of energy intake, and a history of protein intake with the incidence of stunting at 6 to 24 months of age in Central Java province.

Method: This study used an observational analytic study design with a cross-sectional approach. This study is a secondary data analysis derived from the Central Java Provincial Nutrition Monitoring (PSG) survey in 2017. PSG data include body weight, length of birth, nutritional status, history of exclusive breastfeeding, history of IMD and history of nutrient intake in 6 to 24 months of age. The sample in this study was 3776 under 2 years children's data. Statistical analysis with univariate form of frequency distribution. Bivariate analysis uses chi-square test to determine the relationship between variables. Logistic regression test to determine the magnitude of risk in the independent variable with the occurrence of stunting.

Results: The prevalence of stunting under 2 years children in Central Java was 18.5\%. Factors for stunting in the province of Central Java were a history of energy Energi $(p=0.001$ OR 1.495 95\% CI : $1.178-1.897)$, and a history of exclusive breastfeeding ( $p=0.006$ OR $1.28295 \%$ CI : $1.076-1.527$ ).

Conclusions: a history of exclusive breastfeeding, and a history of energy intake are factors of the incidence of stunting in under 2 years children aged 6-24 months in Central Java.
\end{abstract}

Keywords: stunting, early breastfeeding initiation (IMD), exclusive breastfeeding, energy intake, protein intake

\begin{abstract}
ABSTRAK
Latar Belakang: Stunting merupakan gambaran dari status gizi yang kurang yang bersifat kronik. Banyak faktor yang mempengaruhi stunting. Penelitian ini bertujuan untuk mengetahui hubungan antara riwayat inisiasi menyusu dini (IMD), riwayat ASI eksklusif, riwayat asupan energi, dan riwayat asupan protein dengan kejadian stunting pada usia 6 - 24 bulan di provinsi Jawa Tengah.

Metode : Penelitian ini menggunakan rancangan studi analitik observasional dengan pendekatan Cross-sectional. Penelitian ini merupakan analisis data sekunder yang berasal dari survey Pemantauan Status Gizi (PSG) provinsi Jawa Tengah tahun 2017. Sejumlah 3.776 sampel yang memenuhi kriteria inklusi yaitu berusia 6-24 bulan yang terdaftar pada data PSG provinsi Jawa Tengah tahun 2017. Data PSG meliputi data berat badan, panjang lahir, status gizi, riwayat ASI eksklusif, riwayat IMD, dan riwayat asupan zat gizi pada usia 6-24 bulan. Analisis statistik dengan univariat berupa distribusi frekuensi. Analisis bivariat menggunakan uji chi-square untuk mengetahui hubungan antar variabel. Uji regresi logistik untuk mengetahui besar risiko pada variabel bebas dengan kejadian stunting.

Hasil: Prevalensi stunting usia 6-24 bulan di Jawa Tengah sejumlah 18,5\%. Faktor kejadian stunting di provinsi Jawa Tengah adalah Asupan Energi ( $p=0,001$ OR 1,495 95\% CI : 1,178-1,897), dan riwayat ASI Eksklusif ( $p=0,006$ OR 1,282 95\% CI : 1,076-1,527).

Simpulan: Riwayat ASI eksklusif dan riwayat asupan energi merupakan fakor kejadian stunting pada usia 6 -24 bulan di provinsi Jawa Tengah.
\end{abstract}

Kata kunci: stunting, insiasi menyusu dini (IMD), ASI eksklusif, asupan energi, asupan protein

\section{PENDAHULUAN}

Perkembangan masalah gizi di Indonesia sangat kompleks, permasalahan tersebut mengacu pada kekurangan gizi dan kelebihan gizi yang harus di tangani dengan serius. Saat ini prioritas pemerintah fokus terhadap 1000 hari pertama kehidupan untuk menyelesaikan masalah gizi dan terutama masalah stunting. Seribu hari pertama kehidupan seorang anak merupakan masa kritis yang dapat menentukan masa depannya, saat ini anak di Indonesia menghadapi gangguan pertumbuhan yang serius. Indonesia ikut serta dalam komitmen global (SUN - Scalling $U p$ Nutrition) dalam menurunkan stunting. ${ }^{1}$

Stunting menggambarkan status gizi kurang yang bersifat kronik, keadaan ini dipresentasikan dengan nilai $z$-score tinggi badan menurut umur 
(TB/U) pada ambang batas <-2 SD sampai dengan -3 SD (pendek/stunting) dan <-3 (sangat pendek). Sekitar satu dari empat anak dibawah usia 5 tahun mengalami stunting, yaitu $26 \%$ pada tahun $2011 .^{2}$ Masalah stunting/pendek pada balita di Indonesia tergolong cukup serius, tahun 2010 angka stunting sebesar 35,6\% dan terjadi peningkatan pada tahun 2013 yaitu sebesar 37,2\% dan terjadi penurunan pada tahun 2018, dimana angka stunting mencapai 30,8\% balita stunting. ${ }^{3,4}$ Provinsi Jawa Tengah terbagi atas 29 Kabupaten dan 6 kota. Prevalensi stunting di provinsi Jawa Tengah sebesar $28.5 \%$ pada tahun 2017. Terdapat kabupaten / kota di Jawa tengah yang menjadi prioritas penurunan stunting yaitu Cilacap, Banyumas, Purbalingga, Kebumen, Wonosonbo, Klaten, Grobogan, Blora, Demak, Pemalang, Berebes dan Pekalongan. ${ }^{5,6,7,8}$

Inisiasi Menyusu Dini (IMD) dilakukan saat bayi lahir dan bayi segera menyusu secara mandiri. Bayi dibiarkan untuk kontak kulit dengan ibunya, cara melakukan IMD ini disebut dengan the breast crawl atau merangkak mencari payudara sendiri. Inisiasi menyusu dini dilakukan setidaknya satu jam, IMD menjadi salah satu faktor risiko terjadinya stunting penelitian di Bhutan menunjukan bahwa anak yang tidak mendapatkan IMD lebih berisiko mengalami stunting 9,5 kali dibandingkan dengan anak yang mendapatkan IMD. ${ }^{9,10}$

Anak yang tidak diberikan ASI Esklusif pada usia $0-6$ bulan dan pemberian MP-ASI yang tidak sesuai, anak akan dapat berdampak stunting dan akan sering terkena infeksi. ${ }^{11,12}$ ASI Eksklusif merupakan penentu penting pada status gizi pertmbuhan dan perkembangan anak. Pada penelitian di Kenya pada tahun 2014 ditemukan bahwa ada hubungan antara pemberian ASI eksklusif dengan pertumbuan dan stunting pada anak. ${ }^{13}$ Asupan gizi menjadi salah satu penunjang tumbuh dan kembang balita, asupan gizi menjadi gambaran pertumbuhan dan perkembangan yang baik untuk anak pada masa yang akan datang. Asupan menjadi salah satu penyebab dari kejadian stunting. Terpenuhinya kebutuhan anak dilihat dari pola asuh pemberian makan yang kreatif dan variatif yang disediakan oleh ibu. ${ }^{14}$

Asupan energi pada kelompok balita stunting cenderung lebih rendah dibandingkan dengan balita yang tidak stunting, hal tersebut ditunjukan pada penelitian di Mesir yang menyatakan bahwa adanya perbedaan yang signifikan dengan kelompok balita stunting dan tidak stunting. ${ }^{15} \mathrm{Hal}$ ini menyebabkan kekurangan energi kronik (KEK) dalam jangka waktu yang lama dan dapat menyebabkan pertumbuhan liner terganggu. Kekurangan energi juga dapat menyebabkan insulin plasma berkurang sehingga dapat menurunkan sintesis Liver Insulin Growth Factor (IGF), mempengaruhi kinerja IGF binding protein-1, hormone tirid, dan faktor sistemik lainnya yang terlibat dalam Fibroblast growth factor (FGF21) yang semua itu berperan dalam pertumbuhan linier. ${ }^{16}$

Protein dibutuhkan sebagai zat yang dapat membangun, menjaga dan memperbaiki jaringan tubuh. Asupan protein menyediakan asam amino yang diperlukan tubuh untuk membangun matriks tulang dan mempengaruhi pertumbuhan tulang karena protein berfungsi untuk memodifikasi sekresi dan aksi osteotropic hormone, Insulin Growth Factor Binding Protein-1 (IGF-I), sehingga apabila asupan protein rendah terbukti dapat merusak mineral massa tulang dan merusak produksi dan efek IGF-I. tentu saja protein berperan dalam pertumbuhan. ${ }^{16}$ Anakanak yang yang mengalami keterbatasan asam amino esensial seperti tryptophan dan lysine dalam asupan mereka, memiliki risiko tinggi mengalami stunting. Selain itu Penelitian di kota Pontianak menunjukan bahwa asupan protein pada anak stunting lebih rendah dibandingkan anak tidak stunting. ${ }^{17,18}$

Penelitian mengenai determinan faktor terjadinya stunting sudah ada, namun belum ada penelitian yang menunjukan determinan faktor terjadinya stunting yang dikaji berdasarkan provinsi dan berdasarkan data PSG dari provinsi Jawa Tengah. Oleh karena itu, peneliti ingin mengetahui determinan faktor terjadinya Stunting pada usia $6-24$ bulan di provinsi Jawa Tengah.

\section{METODE}

Penelitian ini merupakan penelitian dalam ruang lingkup gizi masyarakat dan penelitian ini menggunakan rancangan studi analitik observasional dengan pendekatan Cross sectional. Penelitian menggunakan data PSG Provinsi Jawa Tengah tahun 2017 ini digunakan untuk melihat determinan faktor terjadinya stunting di Provinsi Jawa Tengah, dimana variable bebas pada penelitian ini merupakan riwayat Inisiasi Menyusu Dini (IMD) dan riwayat ASI eksklusif, asupan energi, dan asupan potein pada usia 6-24 bulan. Sedangkan variable terikatnya adalah kejadian stunting. Subjek penelitian berusia 6-24 bulan di provinsi jawa tengah yang terdaftar pada data PSG provinsi Jawa Tengah tahun 2017. Pengambilan sampel dilakukan dengan Incidental Sampling yakni dengan menentukan karakteristik sampel terlebih dahulu dan memilih seluruh sampel yang memenuhi karakteristik tersebut tanpa menentukan jumlah minimal sampel. Penelitian ini telah mendapat persetujuan layak etik dari Fakultas Kedokteran Undip (No. 423/EC/KEPK/FK UNDIP/X/2019)

Data Variabel bebas pada penelitian ini didapatkan dengan pengisian kuisioner dan hasil wawancara oleh tim Manajemen data dari Direktorat Gizi Masyarakat dan Balitbangkes Kementerian 
Kesehatan. Data riwayat ASI eksklusif dinyatakan dengan Hasil ukur ya dan tidak. Data riwayat pemberian Inisiasi Menyusu Dini (IMD) dinyatakan dengan hasil ukur ya dan tidak. Data Kategori asupan energi dinyatakan dengan hasil cukup dan kurang. Sedangkan data kategori asupan protein dinyatakan dengan hasil cukup dan kurang.

Data Pemantauan Status Gizi (PSG) Provinsi Jawa Tengah tahun 2017 dilakukan oleh Tim Manajemen data dari Direktorat Gizi Masyarakat dan
Balitbangkes Kementerian Kesehatan. Survei PSG ini dilakukan pada bulan maret-oktober tahun 2017 di provinsi Jawa Tengah. Pengumpulan data dilakukan dengan desain potong lintang. Populasi dalam PSG ini adalah semua rumah tangga yang mempunyai balita usia $0-59$ bulan dan semua rumah tangga yang memiliki ibu hamil namun berbeda dengan rumah tangga balita. Pengambilan sampel dijelaskan pada Gambar 1.

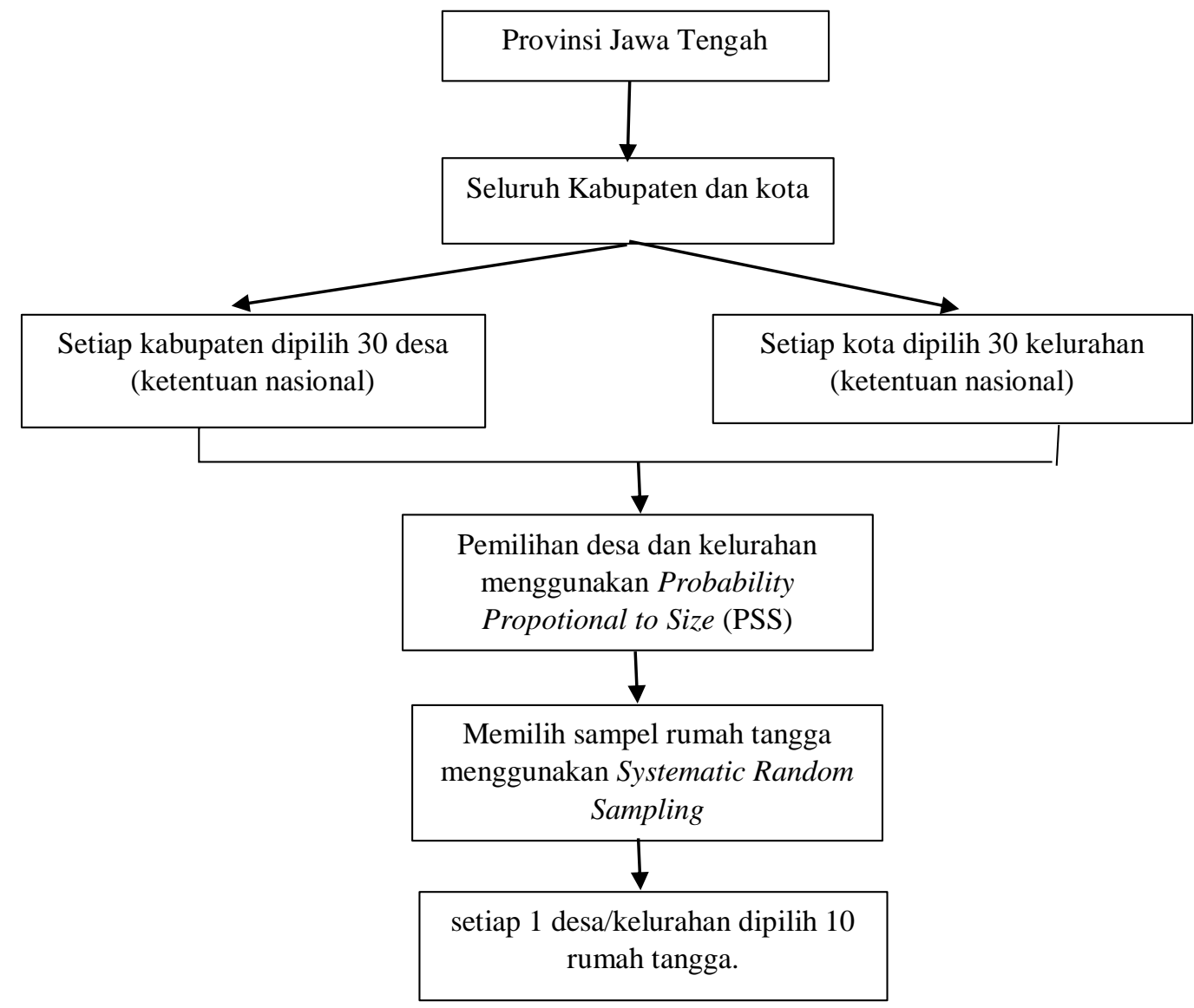

Gambar 1. Pengambilan Sampel oleh Tim PSG

Selanjutnya data divalidasi oleh Direkorat Gizi Kemenkes RI, diperoleh total sampel 11.314 balita berusia 0-59 bulan. Penelitian ini menggunakan karakteristik usia $6-24$ bulan sehingga terdapat 4.118 subjek, setelah itu dilakukan cleaning data untuk menghilangkan data yang tidak terisi dengan lengkap, setelah dilakukan cleaning data, total sampel pada penelitian ini ialah sebesar 3.776 subjek.

Pengambilan data terkait data identitas rumah tangga dan responden, serta data monitoring dan evaluasi kegiatan pembinaan gizi (riwayat ASI eksklusif, riwayat IMD, pemberian PMT) menggunakan kuesioner. Untuk mengukur antropometri menggunakan alat ukur berat badan digital, alat ukur panjang badan bayi, dan untuk subjek yang sudah bisa berdiri tegak, menggunakan microtoise $(200 \mathrm{~cm})$. Sedangkan riwayat asupan makan menggunakan metode food recall 1 x 24 jam. Pengambilan data dilakukan oleh petugas kesehatan yang terampil.

Data yang diperoleh kemudian dianalisis secara statistik dengan program komputer. Analisis Univariat terlebih dahulu dilakukan untuk melihat besar proporsi usia, stunting, riwayat ASI eksklusif dan riwayat IMD, asupan energi dan asupan protein. Analisis bivariat diuji dengan uji Chi Square dengan tingkat keteliian $95 \%$ atau $p$ value $<0,05$ untuk melihat hubungan antara stunting dengan riwayat pemberian ASI Eksklusif dan hubungan stunting dengan riwayat pemberian Inisiasi Menyusu Dini (IMD, hubungan antara stunting dengan asupan energi, dan hubungan antara stunting dengan asupan 
protein. Untuk melihat faktor yang utama akan dilakukan analisis multivariat yang diuji dengan uji regresi logistic dengan $p$ value $<0,25$.

\section{HASIL}

\section{Karakteristik Subjek}

Karakteristik subjek pada penelitian ini terdiri dari usia, tinggi badan, riwayat inisiasi menyusu dini, riwayat ASI eksklusif, asupan energi dan asupan protein. Penelitian ini melibatkan 3.776 subjek dengan rentan usia 6-24 bulan disajikan dalam Tabel 1 .

Tabel 1 menunjukan bahwa stunting di provinsi jawa tengah sebanyak $700(18,5 \%)$, tidak stunting sebesar 3076 (81,5\%), subjek yang melakukan IMD sebesar $318(8,4 \%)$ dan subjek yang tidak melakukan IMD 3458 (91,6\%), selain itu sebesar 1589 (42,1\%) menjalani ASI Eksklusif, sedangkan subjek yang tidak ASI Eksklusif 2187 (57,9\%), subjek dengan kategori cukup energi sebesar $640(16,9 \%)$ dan subjek dengan kategori kurang energi sebesar $3.136(83,1 \%)$ serta subjek dengan kategori cukup protein sebesar 3749 (99,3\%) sedangkan subjek dengan kategori kurang protein sebesar $27(0,7 \%)$.
Tabel 1. Karakteristik Subjek

\begin{tabular}{|c|c|c|}
\hline Karakteristik & $\mathbf{n}$ & $(\%)$ \\
\hline \multicolumn{3}{|l|}{ Usia (bulan) } \\
\hline $6-12$ & 1424 & 37,7 \\
\hline $12-24$ & 2352 & 62,7 \\
\hline \multicolumn{3}{|l|}{ Kategori Tinggi Badan } \\
\hline Stunting & 700 & 18,5 \\
\hline Tidak stunting & 3076 & 81,5 \\
\hline \multicolumn{3}{|c|}{$\begin{array}{l}\text { Riwayat Inisiasi Menyusui Dini } \\
\text { (IMD) }\end{array}$} \\
\hline $\mathrm{Ya}$ & 318 & 8,4 \\
\hline Tidak & 3458 & 91,6 \\
\hline \multicolumn{3}{|l|}{ Riwayat ASI Eksklusif } \\
\hline $\mathrm{Ya}$ & 1589 & 42,1 \\
\hline Tidak & 2187 & 57,9 \\
\hline \multicolumn{3}{|l|}{ Asupan Energi } \\
\hline Cukup & 640 & 16,9 \\
\hline Kurang & 3136 & 83,1 \\
\hline \multicolumn{3}{|l|}{ Asupan Protein } \\
\hline Cukup & 3749 & 99,3 \\
\hline Kurang & 27 & 0,7 \\
\hline
\end{tabular}

\section{Frekuensi Stunting Usia 6-24 Bulan di Tingkat} Kabupaten dan Kota di Provinsi Jawa Tengah

Provinsi Jawa tengah memiliki 29 kabupaten dan 6 kota, Frekuensi stunting usia 6-24 bulan pada tingkat kabupaten dapat dilihat pada Gambar 1, dan frekuensi sunting usia 6-24 bulan pada tingkat kota dapat dilihat pada Gambar 2.

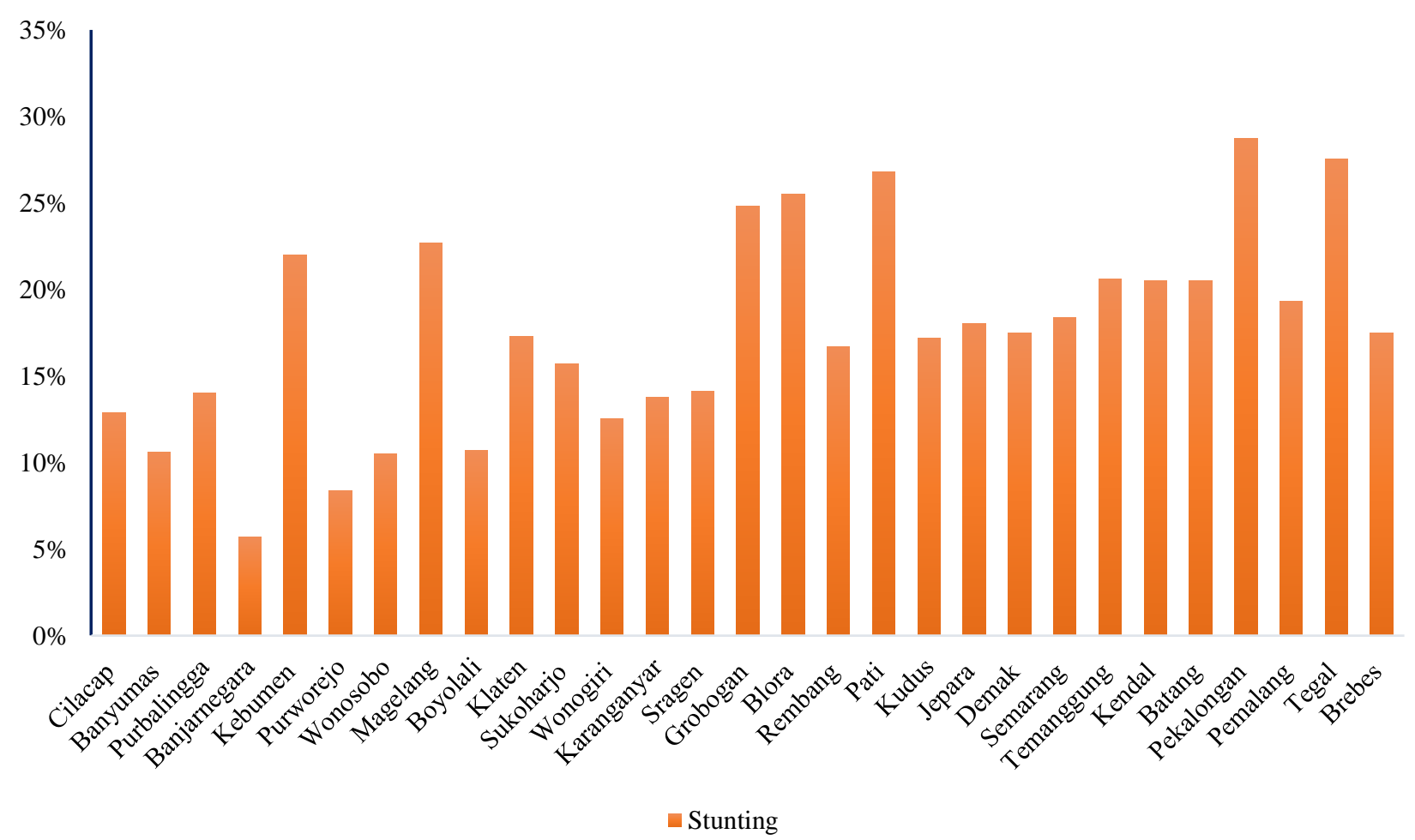

Gambar 2. Frekuensi Stunting Usia 6-24 Bulan di Tingkat Kabupaten

Gambar 2 menunjukan frekuensi stunting usia 6-24 bulan di tingkat kabupaten. Kabuaten dengan frekuensi stunting terbesar ialah kabupaten
Pekalongan (28.7\%) dan kabupaten dengan frekuensi stunting terkecil ialah kabupaten Banjarnegara $(5,7 \%)$. 


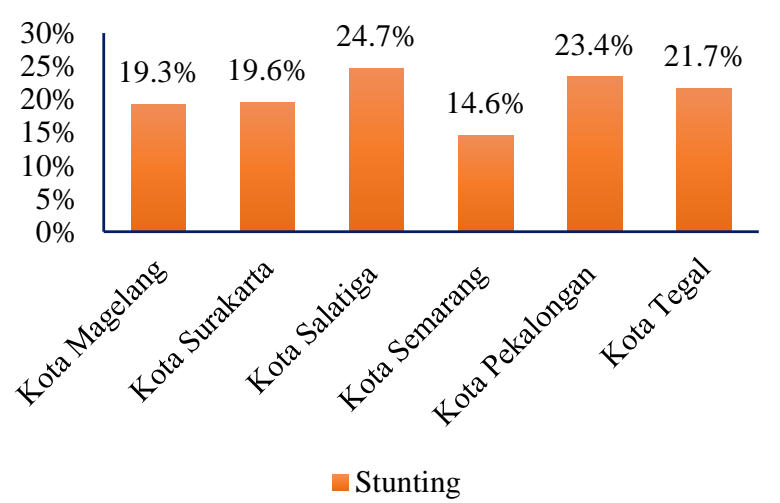

Gambar 3. Frekuensi Stunting usia 6-24 Bulan di Tingkat Kota
Gambar 3 menunjukan frekuensi stunting usia 6-24 bulan di tingkat kota. Kota dengan frekuensi stunting terbesar ialah Kota Salatiga (24,7\%) dan kota dengan frekuensi stunting terkecil ialah Kota Semarang (14,6\%).

Determinan Faktor yang Paling Berhubungan dengan Kejadian Stunting Usia 6-24 Bulan di Provinsi Jawa Tengah

Determinan faktor yang paling berhubungan dengan kejadian stunting dilihat berdasarkan variabel pada penelitian ini yaitu riwayat inisiasi menyusu dini (IMD), riwayat ASI Eksklusif, asupan energi, dan asupan protein. Faktor yang paling berhubungan dapat dilihat pada Tabel 2.

Tabel 2. Faktor yang Berhubungan dengan Kerjadian Stunting

\begin{tabular}{|c|c|c|c|c|c|c|c|c|}
\hline & \multicolumn{2}{|c|}{ Stunting } & \multicolumn{2}{|c|}{$\begin{array}{c}\text { Tidak } \\
\text { stunting }\end{array}$} & \multicolumn{2}{|c|}{ Odds ratio $(95 \% \mathrm{CI})$} & \multicolumn{2}{|c|}{$p^{a}$} \\
\hline & $\mathbf{n}$ & $\%$ & $\mathbf{n}$ & $\%$ & Crude & Adjusted & Crude & Adjusted \\
\hline \multicolumn{9}{|c|}{$\begin{array}{l}\text { Inisiasi Menyusui Dini } \\
\text { (IMD) }\end{array}$} \\
\hline $\mathrm{Ya}$ & 41 & 12,9 & 277 & 87,1 & 1 & 1 & & \\
\hline Tidak & 659 & 19,1 & 2799 & 80.9 & $\begin{array}{c}1,560 \\
(1,110-2,191)\end{array}$ & $\begin{array}{c}1,407 \\
(0,990-2,000)\end{array}$ & $0,010 *$ & 0,057 \\
\hline \multicolumn{9}{|c|}{ ASI Eksklusif } \\
\hline $\mathrm{Ya}$ & 271 & 82,9 & 1318 & 82,9 & 1 & 1 & & \\
\hline Tidak & 429 & 19,6 & 1758 & 80,4 & $\begin{array}{c}1,186 \\
(1,002-1,405)\end{array}$ & $\begin{array}{c}1,282 \\
(1,076-1,527)\end{array}$ & $0,048^{*}$ & $0,006^{*}$ \\
\hline \multicolumn{9}{|c|}{ Asupan Energi } \\
\hline Cukup & 100 & 15,6 & 540 & 84,4 & 1 & 1 & & \\
\hline Kurang & 600 & 19,1 & 2536 & 80,9 & $\begin{array}{c}1,293 \\
(1,293-1,025)\end{array}$ & $\begin{array}{c}1,495 \\
(1,178-1,897)\end{array}$ & $0,030 *$ & $0,001^{*}$ \\
\hline \multicolumn{9}{|c|}{ Asupan Protein } \\
\hline Cukup & 693 & 18,5 & 3056 & 81,5 & 1 & 1 & & \\
\hline Kurang & 7 & 25,9 & 20 & 74,1 & $\begin{array}{c}1,555 \\
(0,652-3,707)\end{array}$ & $\begin{array}{c}2,235 \\
(0.872-5,728)\end{array}$ & 0,319 & 0,094 \\
\hline
\end{tabular}

Tabel 2 menunjukan setelah di uji dengan regresi logistic, variabel yang menjadi faktor terjadinya stunting usia 6-24 bulan di provinsi Jawa Tengah adalah ASI eksklusif $(p=0,006)$ dan asupan energi kurang ( $p=0,001)$.

\section{PEMBAHASAN}

Prevalensi stunting di provinsi Jawa Tengah sebesar 28,5\% pada tahun 2017.6 Hasil prevalensi tersebut menunjukan bahwa masih diperlukan upaya untuk menurunkan angka stunting usia 6-24 bulan di Jawa Tengah. Penelitian ini menunjukan 18,5\% usia 6-24 bulan mengalami stunting. Prevalensi stunting tersebut berdasarkan data Pemantauan Status Gizi nasional, masih dibawah data nasional. Prevalensi nasional stunting usia 0-24 bulan adalah 20,1\%. Anak yang mengalami stunting dikaitkan dengan perkembangan otak suboptimal, yang dapat mengambat perkembangan anak, seperti penurunan intelektual, rentan terhadap penyakit tidak menular, serta terjadinya kegagalan pertumbuhan intergenerasi yang selalu berlanjut. ${ }^{19,20}$ Selain itu, asupan energi yang kurang memiliki risiko 1,495 kali dengan kejadian stunting. Penelitian ini juga menjelaskan bahwa anak usia 6-24 bulan yang tidak diberikan ASI eksklusif memiliki risiko stunting 1,282 kali dibandingkan anak yang diberikan ASI eksklusif, sehingga riwayat ASI ekskulusif menjadi faktor yang berhubungan dengan kejadian stunting.

Prevalensi stunting menjadi masalah kesehatan apabila prevalensinya mencapai 20\%. Terdapat kabupaten / kota di Jawa tengah yang menjadi prioritas penurunan stunting yaitu Cilacap, Banyumas, Purbalingga, Kebumen, Wonosonbo, Klaten, Grobogan, Blora, Demak, Pemalang, Berebes dan Pekalongan. ${ }^{7}$ Stunting dipengaruhi oleh berbagai faktor, salah satunya adalah ekonomi. Badan Pusat Statistik Jawa Tengah mengungkapkan bahwa sebagian besar kabupaten yang berada di Jawa Tengah mengeluarkan 45-60\% uang untuk alokasi 
belanja makanan. ${ }^{21}$ Sedangkan angka kemiskinan pada beberapa kabupaten di Jawa Tengah berada pada kisaran 10-20\%. Angka kemiskinan tersebut masih tinggi, sesuai dengan sasaran pengurangan kemiskinan RPJM tahun 2017 adalah sebesar 6-8\%.22 kemiskinan menjadi faktor dengan kontribusi besar terhadap tingginya prevalensi stunting. Konsep pertumbuhan dan perkembangan menyatakan bahwa faktor sosio ekonomi merupakan variabel yang berpengaruh terhadap kualitas pertumbuhan dan perkembangan. Kemiskinan dikaitkan dengan daya beli, sehingga akan mempengaruhi akses keluarga dalam mencari maupun menyediakan makanan yang bergizi, bersih dan sehat. ${ }^{23}$ Selain itu, kualitas air juga mempengaruhi tingginya angka prevalensi stunting di Jawa Tengah ${ }^{24,25}$

Hasil pada penelitian ini tidak semua lokus memiliki besar masalah stunting yang mencapai $20 \%$, hal ini dapat dikarenakan data yang digunakan pada penelitian ini menggunakan karakteristik usia 6-24 bulan, dan berdasarkan kebijakan pemerintah, penentuan lokus stunting kabupaten dan kota di tentukan dengan besaran masalah lebih dari $20 \%$ dengan rentan usia 0-59 bulan. Hasil besaran stunting di tingkat kota menunjukan 3 dari 6 kota memiliki prevalensi stunting yang mencapai $20 \%$, yaitu kota Salatiga $(24,7 \%)$, Kota pekalongan $(23,4 \%)$ dan kota tegal $(21,7 \%)$.

Asupan energi yang kurang memiliki risiko 1,495 kali dengan kejadian stunting. Hal ini sejalan dengan penelitian sebelumnya di kota manado yang memiliki hubungan positif antara asupan energi yang kurang dengan kejadian stunting. Selain itu penelitian di kabupaten brebes menunjukan bahwa faktor risiko yang mempengaruhi kejadian stunting di kabupaten brebes adalah rendahnya tingkat asupan energi dengn besar risiko 7,7 kali. ${ }^{26,27}$ Energi menjadi salah satu faktor dalam pertumbuhan, jika kekurangan energi kronik (KEK) dalam jangka waktu yang lama dan dapat menyebabkan pertumbuhan liner terganggu. ${ }^{16}$

Anak usia 6-24 bulan yang tidak diberikan ASI eksklusif memiliki risiko stunting 1,282 kali dibandingkan anak yang diberikan ASI eksklusif, sehingga riwayat ASI ekskulusif menjadi faktor yang berhubungan dengan kejadian stunting. Hasil ini sejalan dengan penelitian yang dilakukan di kota Pekanbaru yang menunjukan $41,8 \%$ balita yang tidak ASI eksklusif mengalami stunting sehingga pada penelitian ini menunjukan adanya hubungan yang bermakna antara ASI eksklusif dengan kejadian stunting. ${ }^{28}$ Penelitian di Surakarta dan Banda Aceh juga menunjukan adanya hubungan ASI Eksklusif dan stunting pada anak. ${ }^{29,30}$ ASI merupakan makanan yang paling baik bagi bayi, ASI Ekslusif diberikan selama 6 bulan tanpa ada tambahan makanan lain, dan dapat dilanjutkan hingga bayi berusia 2 tahun. ASI dapat menurunkan angka kematian bayi. Kandungan ASI yang kaya dengan zat gizi dapat memperkecil risiko bayi terserang penyakit infeksi, penyakit infeksi dapat meningkatkan malnutrisi, sehingga apabila terjadi dalam jangka panjang dapat menganggu absorbsi zat gizi, sehingga dapat meningkatkan risiko terjadinya stunting pada anak balita. ${ }^{28,31}$

ASI memiliki kandungan kolostrum, kolostrum mengandung leukosit sebanyak $5 \times 10^{6}$ sel per $\mathrm{ml}$, dan akan menurun seiring lamanya menyusui. Leukosit berupa makrofag yang dapat melawan mikroba pathogen. ${ }^{32}$ anak yang mendapatkan kolostrum yang mengandung antibodi dan membantu pertumbuhan usus dan ketahanan terhadap infeksi. Kolostrum mengandung protein dan immunoglobulin A (IgA) yang dapat melindungi saluran cerna bayi, sel imunitas yang terdapat pada kolustum mengandung enzim lisozim untuk menghambat pertumbuhan berbagai macam bakteri. ${ }^{32,33}$ kandungan zat gizi pada ASI sangat sesuai dengan tumbuh dan kembang anak secara optimal.

Kandungan zat gizi dalam ASI diantaranya adalah energi yang memiliki kontribusi yang sangat besar yang berasal dari protein, karbohidrat dan lemak. Zat gizi seperti vitamin A, vitamin D, vitamin B6, kalsium, zat besi dan juga seng merupakan kandungan zat gizi pada ASI yang dibutuhkan oleh anak. ${ }^{17,34}$ Kekurangan zat besi dapat menyebabkan gangguan kognitif dan fisik dan peningkatan risiko kemarian. Zat besi memegang peran mengedar oksigen ke semua jaringan tubuh. Jika oksigenasi ke jaringan tulang berkurang, maka tulang tidak akan dapat tumbuh dngan maksimal. Sehingga balita yang mengalami defisiensi zat besi dapat berisiko mengalami stunting. ${ }^{25}$ Peran Vitamin D dalam pertumbuhan salah satunya membantu pengerasan tulang yang mengatur kalsium dan fosfor dapat diendapkan didalam darah untuk proses pengerasan tulang. ${ }^{35}$ Kelebihan pada penelitian adalah besar sampel yang besar yang bisa mewakili populasi keseluruhan di Jawa Tengah. Namun penelitian ini juga memiliki kekurangan yaitu desain crosssectional yang tidak bisa menggambarkan hubungan sebab akibat. Kemudian beberapa faktor perancu yang mungkin ada namun tidak dapat diambil datanya seperti sosial ekonomi.

\section{SIMPULAN}

Asupan energi yang kurang pada anak usia 624 bulan memiiliki risiko sebesar 1,495 kali mengalami stunting dan memiliki risiko paling kecil 1,178 kali dan paling besar 1,897 kali dibandingkan dengan anak yang memiliki asupan energi cukup. 
Anak yang tidak diberikan ASI eksklusif berisiko 1,282 kali mengalami stunting dengan risiko paling kecil 1,076 kali dan paling besar 1,527 kali dibandingkan anak yang diberikan ASI eksklusif. Perlu penelitian lebih lanjut dengan menggunakan desain penelitian longitudinal tentang faktor-faktor yang berkaitan dengan kejadian stunting.

\section{UCAPAN TERIMA KASIH}

Peneliti mengucapkan terima kasih kepada Dinas Kesehatan Provinsi Jawa Tengah terkhusus bagian kesehatan keluarga dan gizi, direktrorat gizi Poltekkes Kemenkes Semarang yang tergabung dalam tim pemantauan status gizi (PSG) provinsi Jawa Tengah Tahun 2017 yang telah memberikan izin peneliti menggunakan data PSG provinsi Jawa Tengah tahun 2017. Terima kasih kepada semua pihak yang telah mendukung peneliti sehingga penelitiaan ini dapat diselesaikan.

\section{DAFTAR PUSTAKA}

1. Kementerian Kesehatan RI. Rencana Strategis Kementerian Kesehatan Republik Indonesia Tahun 2015-2019. Jakarta: Pusat Komunikasi Publik; 2014.p 21.

2. UNICEF. Improving Child Nutrition: The Achievable Imperative for Global Progress. Division of Communication, UNICEF;2013.

3. Badan Penelitian dan Pengembangan Kesehatan. Riset Kesehatan Dasar (RISKESDAS) 2013. Jakarta: Kemenkes RI; 2013.

4. Kementerian Kesehatan RI. Hasil Utama Riset Kesehatan Dasar 2018. Jakarta: Kemeskes; 2018. p 9.

5. Provinsi Jawa Tengah Dalam Angka 2018. Semarang: Badan Pusat Statistik Jawa Tengah; 2018. p 7.

6. Sunarto, Yazid A, Rinaningsih, Hasanuddin M. Laporan Pemantauan Status Gizi Jawa Tengah Tahun 2017. Semarang: Dinas Kesehatan Provinsi Jawa Tengah dan Poltekkes Kemenkes Semarang; 2017. p 14

7. Tim Nasional Percepatan Penanggulangan Kemiskinan (TNP2K). Gerakan Nasional Pencegahan Stunting dan Kerjasama Kemitraan Multi Sektor. 2017. 1-42

8. Kementerian Kesehatan RI. Peraturan Menteri Kesehatan Republik Indonesia Nomor 39 Tahun 2016 tentang Pedoman Penyelenggaraan Program Indonesia Sehat Dengan Pendekatan Keluarga. Jakarta; Kemenkes RI; 2016. 31-48

9. Adam A, Alim A, Sari NP. Pemberian inisiasi menyusu dini pada bayi baru lahir. Jurnal Kesehatan Manarang. 2019;2(2):76.

10. Aguayo VM, Badgaiyan N, Paintal K. Determinants of child stunting in the Royal
Kingdom of Bhutan: an in-depth analysis of nationally representative data. Matern Child Nutr. 2014;(Unicef):1-13.

11. Sukmawati, Hendrayati, Chaerunnimah, Nurhumaira. Status Gizi Ibu Saat Hamil, Berat Badan Lahir Bayi dengan Stunting Pada Balita. Media Gizi Pangan. 2018;25:18-25.

12. Senbanjo IO, Oshikoya KA, Odusanya OO, Njokanma OF. Prevalence of and risk factors for stunting among school children and adolescents in Abeokuta, Southwest Nigeria. J Heal Popul Nutr. 2011;29(4):364-70.

13. Sciences $\mathrm{C}$. Exclusive breastfeeding practice : its implication on nutrition status, growth and morbidity pattern among infants aged 0-6 months. Glob J Biol Agric Heal Sci. 2014;3(1):254-8.

14. Loya RRP, Nuryanto N. Pola asuh pemberian makan pada bayi stunting usia 6-12 bulan di Kabupaten Sumba Tengah, Nusa Tenggara Timur. Journal of Nutrition College. 2019;6(1):84.

15. Khairy SA, Salem HYHA, Samy MA. Effect of nutritional status on growth pattern of stunted preschool children in Egypt. Acad J Nutr. 2013;2(1):1-9.

16. Gat-yablonski G, Phillip M. NutritionallyInduced catch-up growth. Nutrients. 2015; 7(1):517-51.

17. Vaozia S, Nuryanto. Faktor Risiko Kejadian Stunting Pada Anak Usia 1 - 3 Tahun (Studi di Desa Menduran Kecamatan Brati Kabupaten Grobogan). Journal of Nutrition College. 2016;5(4):314-20.

18. Sari EM, Juffrie M, Nurani N, Sitaresmi MN. Asupan protein, kalsium dan fosfor pada anak stunting dan tidak stunting usia 24-59 bulan. Jurnal Gizi Klinik Indonesia. 2017;12(4):152159.

19. Kusharisupeni. Growth Faltering Pada Bayi Di Kabupaten Indramayu Jawa Barat. Makara Kesehatan. 2002;6(1):1-5.

20. Ni'mah K, Nadhiroh siti rahayu. Faktor yang berhubungan dengan kejadian stunting pada balita. Media Gizi Indonesia. 2015;10(1):13-9.

21. Pemerataan Pendapata dan Pola Konsumsi Penduduk Jawa Tengah. Semarang: Badan Pusat Statistik Jawa Tengah; 2017. p. 101.

22. Harmadi SHB. Tanggapan atas Rancangan Teknokratik RPJMN 2015 - 2019 bidang Sosial Budaya, Sarpas, dan Wilayah Tata Ruang dengan Penekanan Pada Substansi Kemiskinan. Lembaga Demografi FEUI; 2019. p. 8.

23. Laksono AD, Kusrini I. Overview of Stunting Prevalence of Toddlers and Related Factors in Indonesia: Advance Analysis of the 2017 
Indonesian Health Profile. 2019.

24. Setyaningsih N, Anna AN, Cholil M. Analisis kesadahan air tanah di kecamatan toroh kabupaten grobogan propinsi jawa tengah. Universitas Muhammadiyah Surakarta. Skripsi, 2014.

25. Petry N, Olofin I, Boy E, Angel MD, Rohner F. The effect of low dose iron and zinc intake on child micronutrient status and development during the first 1000 days of life: a systematic review and meta-analysis. Nutrients, 2016;8(12): 773

26. Tangkudung GSJ. Hubungan antara asupan energi dengan kejadian stunting pada anak usia 13-36 bulan di wilayah kerja puskesmas tuminting kota Manado. Fakultas Kesehatan Masyarakat Universitas San Ratulangi, 2014.

27. Wellina WF, Kartasurya MI, Rahfilludin MZ. Faktor risiko stunting pada anak umur 12-24 bulan. Jurnal Gizi Indonesia (The Indonesian Journal of Nutrition), 2016;5(1):55-61.

28. FItri L. Hubungan BBLR dan ASI eksklusif dengan kejadian stunting di puskesmas Lima Puluh Pekan Baru. Jurnal Endurance. 2018;3(1):131-7.

29. Lestari ED, Hasanah F, Nugroho NA. Correlation between non-exclusive breastfeeding and low birth weight to stunting in children. Paediatrica Indonesiana. 2018;58(3):123-7.

30. Al-Rahmat AH, Miko A, Hadi A. Kajian stunting pada anak balita ditinjau dari pemberian ASI eksklusif, MP ASI, status imunisasi dan karakteristik keluarga di kota Banda Aceh. Jurnal Kesehatan Ilmiah Nasuwakes. 2013;6(2):169-184
31. Mentari S, Hermansyah A. Faktor - faktor yang berhubungan dengan status stunting anak usia 24 - 59 bulan di wilayah kerja UPK puskesmas Siantan Hulu. Pontianak Nutrition Journal. 2018;1(1):1-5.

32. Febriani CA, Perdana AA, Humairoh. Faktor kejadian stunting balita berusia 6 - 23 bulan di provinsi Lampung. Jurnal Dunia Kesmas. 2018;7(3):127-33.

33. Kuchenbecker J, Jordan I, Reinbott A, Herrmann J, Jeremias T, Kennedy G, et al. Exclusive breastfeeding and its effect on growth of Malawian infants : results from cross sectional study. Paediatr Int Child Health, 2015;35(1):1423

34. Butte NF, Lopez-alarcon MG, Garza C. Nutrient Adequacy of Exclusive breastfeeding for the term infant during the first six months of life. Geneva: WHO; 2002.

35. Chairunnisa E, Candra A, Panunggal B. Asupan vitamin D, kalsium dan fosfor pada anak stunting dan tidak stunting usia 12 - 24 bulan di Kota Semarang. Journal of Nutrition Collegel. 2018;7(1): 39-44.

36. Rahmaniah R, Huriyati E, Irwanti W. Riwayat asupan energi dan protein yang kurang bukan faktor risiko stunting pada anak usia 6-23 bulan. Jurnal Gizi dan Dietetik Indonesia. 2014;2(3):150-8.

37. Oldewage-theron WH, Dicks EG, Napier CE. Poverty, household food insecurity and nutrition: coping strategies in an informal settlement in the Vaal Triangle, South Africa. Public Helath. 2006;120(9):795-804. 